Proportions of girls aged 10-14 who had reached menarche according to whether they were thin and indulged in intensive sports activity

\begin{tabular}{|c|c|c|c|c|c|c|}
\hline & & & & $\%$ & $\mathrm{SE}^{*}$ & Proportion \\
\hline $\begin{array}{l}\text { Thin: } \\
\text { Intensive sport } \\
\text { No intensive sport }\end{array}$ & $\therefore$ & 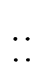 & $\because$. & $\begin{array}{l}15 \\
37\end{array}$ & $\begin{array}{l} \pm 3.4 \\
\pm 4.3\end{array}$ & $\begin{array}{l}16 / 109 \\
47 / 126\end{array}$ \\
\hline $\begin{array}{l}\text { Not thin: } \\
\text { Intensive sport } \\
\text { No intensive sport }\end{array}$ & $\begin{array}{l}\cdots \\
\cdots\end{array}$ & $\begin{array}{l}\cdots \\
\cdots\end{array}$ & $\ddot{n}$ & $\begin{array}{l}47 \\
75\end{array}$ & $\begin{array}{r} \pm 4 \cdot 4 \\
\pm 2 \cdot 6\end{array}$ & $\begin{array}{r}60 / 129 \\
214 / 284\end{array}$ \\
\hline
\end{tabular}

*SE $=$ Standard error

\section{Discussion}

Our data are compatible with the hypothesis that both thinness and physical activity may cause delayed menarche. In addition, the effects of these two factors seem synergistic ${ }^{5}$ : several girls who would have reached menarche if either thinness or intensive sports activity had been present alone had not reached menarche when both factors were present together. Since metabolic changes are probably associated with sports activity and with thinness, synergism of the effects makes sense.

One objection to our analysis is that a certain body mass index might not have the same meaning in a person who is physically active as in a person who is not, owing to different lean:fat ratios. We have no means to correct for this in our data. Other possible objections might be that in subjects aged 10-14 the body mass index rises with age, and that at this critical age drastic changes in physical activity might occur. To take such confounding influences into account we performed the analysis again with smaller age groups, halving the five-year age categorypt The synergistic relation persisted in each of the two resulting age groups. On finer stratification by single years of age thg gradient between the thin and not-thin and sports and no-sports. categories remained in the same direction, though the smallnes( of the numbers made it difficult to judge synergy confidently Thus our data reinforce and refine the earlier hypotheses of Frisch et $a l,{ }^{12}$ particularly since the information was collecte $\$$ during a population survey without obvious selection ang without advance knowledge about the factors entailed in the hypotheses.

This research was supported by grants from the Netherlands Prevention Fund, the Netherlands Organisation for Applied Scientifi Research, and the Netherlands Kidney Foundation.

\section{References}

1 Frisch RE, Wyshak G, Vincent L. Delayed menarche and amenorrhoea in ballet dancers. $N$ Engl $\mathcal{F}$ Med 1980;303:17-9.

${ }^{2}$ Frisch RE, Gotz-Welbergen AV, McArthur JW, et al. Delayed menarch and amenorrhoea of college athletes in relation to age of onset of training. F $A M A$ A $1981 ; 246: 1559-63$.

${ }^{3}$ Vandenbroucke JP, van Laar A, Valkenburg HA. Thinness, delaye menarche and irregular cycles. $N$ Engl f Med 1981 ;305:229-30.

4 Keys A, Fidanza F, Karvonen MJ, Kimura N, Taylor HL. Indices relative weight and obesity. $\mathcal{F}$ Chronic Dis $1972 ; 25: 329-43$.

${ }^{5}$ Rothman KJ, Greenland S, Walker AM. Concepts of interaction. Am Epidemiol 1980;112:467-70.

(Accepted 28 April 1982)

\title{
Bromocriptine in management of large pituitary tumours
}

\author{
J A H WASS, JULIA WILLIAMS, M CHARLESWORTH, D P E KINGSLEY, A M HALLIDAY, \\ I DONIACH, LESLEY H REES, W I MCDONALD, G M BESSER
}

\begin{abstract}
Bromocriptine has an accepted place in the management of small pituitary tumours that secrete either prolactin or growth hormone. The treatment of large tumours with extrasellar extensions is more difficult, however: though surgery is the standard treatment, it is often unsuccessful in returning excessive hormone secretion to normal and may cause hypopituitarism. A prospective trial was undertaken to assess the frequency with which changes in pituitary function and size of large tumours occurs. Nineteen patients were studied before and during treatment with bromocriptine $(7.5$ to $60 \mathrm{mg} /$ day) for three to
\end{abstract}

\footnotetext{
Departments of Endocrinology, Radiology, and Chemical Endocrinology, St Bartholomew's Hospital, London EC1A 7BE

J A H WASS, MD, MRCP, senior lecturer in medicine JULIA WILLIAMS, SRN, research nurse

M CHARLESWORTH, FRCR, consultant radiologist

D P E KINGSLEY, FRCS, FRCR, consultant radiologist

I DONIACH, MD, FRCP, emeritus professor of pathology

LESLEY H REES, MD, FRCP, professor of chemical endocrinology

G M BESSER, MD, FRCP, professor of endocrinology
}

Institute of Neurology, National Hospital for Nervous Diseases, Queen Square, London WC1

A M HALLIDAY, BSC, $\mathrm{MB}$, consultant neurophysiologist

W I MCDONALD, PHD, FRCP, professor of clinical neurology
22 months, using contrast radiology and a detailed assess? ment of pituitary function. Eighteen patients had hyper prolactinaemia and two of these also had raised concen trations of growth hormone; one patient had an apparent: ly non-functioning tumour. In 12 patients $(63 \%)$ tumour size decreased with bromocriptine and no tumoug enlarged. Nine patients had visual-field defects, which improved in seven, becoming normal in five. Pituitar function improved in nine patients $(47 \%)$ becoming entirely normal in three.

Bromocriptine should be the treatment of choice is patients with large pituitary tumours with extrasellar extensions, provided close supervision is maintained.

\section{Introduction}

Bromocriptine, a long-acting dopamine agonist, lowers abnorma circulating hormone concentrations in patients with smalt pituitary tumours that secrete prolactin and growth hormone? and it has an accepted place in their management. ${ }^{1-6}$ The bes: treatment for large pituitary tumours that extend out of the sellig turcica, however, is more difficult and controversial. Mostly these tumours secrete prolactin though they may be truly non functioning or, more rarely, secrete either growth hormone of adrenocorticotrophin. ${ }^{7}$ Urgent surgical decompression is nor mally recommended if the tumour extends upwards to a a r ect the visual pathways or laterally to affect the oculomotor nerve. 
The operation may be performed using either the transfrontal or transsphenoidal routes, either of which is usually locally satisfactory, but both have a morbidity and hormonal cure is rare and hypopituitarism frequent. ${ }^{2} 89$ External pituitary irradiation is contraindicated in extensive extrasellar extension since further swelling may occur during treatment. Several reports suggest that prolactinomas and tumours associated with acromegaly may shrink with an improvement in pituitary hormonal state, and visual-field defects may improve in some patients, ${ }^{510-16}$ though the overall frequency of such beneficial responses is still not clear. It therefore seemed that dopamine agonist treatment should be considered in large extrasellar extensions to reduce the pituitary tumour mass in patients who would otherwise be submitted to urgent hypophysectomy.

We carried out a prospective collaborative trial in 19 consecutive patients to evaluate the incidence of a decrease in size of large tumours treated with bromocriptine alone. Pneumoencephalography or metrizamide cisternography were performed in addition to computed tomography (CT) to assess pituitary tumour size before and after at least three months of treatment. In addition, we carried out a detailed assessment of pituitary function before and during treatment and have shown that in contrast to other modes of treatment for large pituitary tumours, pituitary function often improves as the tumour mass shrinks.

\section{Patients and methods}

Nineteen consecutive patients ( 11 women and eight men, aged 22 to 70 years) with extrasellar extensions to their pituitary tumours were

TABLE I-Details of patients studied

\begin{tabular}{|c|c|c|c|c|c|}
\hline Case No & Sex & Age (yrs) & $\begin{array}{l}\text { Previous } \\
\text { treatment }\end{array}$ & $\underset{(\mathrm{mg} / \mathrm{day})}{\text { Bromocriptine }}$ & $\begin{array}{c}\text { Follow-up } \\
\text { (months) }\end{array}$ \\
\hline 1 & $\mathrm{~F}$ & 58 & \multirow{6}{*}{$\begin{array}{c}\text { Nil } \\
\text { ", } \\
\text { Surgery and } \\
\text { radiotherapy } \\
\text { Surgery and } \\
\text { radiotherapy } \\
\text { Nil }\end{array}$} & 30 & 15 \\
\hline 2 & $M$ & 32 & & 60 & 3 \\
\hline 3 & $M$ & 29 & & & 18 \\
\hline 4 & $\mathrm{~F}$ & 70 & & $7 \cdot 5$ & 3 \\
\hline 5 & F & 39 & & 30 & 6 \\
\hline & $M$ & & & 30 & 4 \\
\hline 7 & $M$ & 49 & Nil & 7.5 & $\begin{array}{l}4 \\
4\end{array}$ \\
\hline 8 & $\mathrm{~F}$ & 22 & ”, & 7.5 & 22 \\
\hline 9 & $\mathrm{~F}$ & 25 & ", & 15 & 3 \\
\hline 10 & $M$ & 44 & ” & 30 & 16 \\
\hline 11 & $\mathrm{~F}$ & 50 & ", & $7 \cdot 5$ & 3 \\
\hline 12 & $\mathrm{~F}$ & 25 & ”, & 15 & 6 \\
\hline 13 & $\mathrm{~F}$ & 28 & ”, & $7 \cdot 5$ & 5 \\
\hline 14 & $M$ & 68 & "” & 7.5 & 12 \\
\hline 15 & $\mathrm{~F}$ & 22 & ” & 7.5 & 3 \\
\hline 16 & $\mathrm{~F}$ & 31 & ” & 7.5 & 12 \\
\hline 17 & $\mathrm{~F}$ & 23 & "” & 7.5 & 4 \\
\hline 18 & $M$ & 22 & ”, & 20 & 3 \\
\hline 19 & M & 43 & ", & $7 \cdot 5$ & 3 \\
\hline
\end{tabular}

studied (table I). Two patients had had surgery and radiotherapy elsewhere four and 13 years previously but presented again with worsening visual field defects; the other patients had had no treatment for their pituitary tumour. Eighteen were hyperprolactinaemic (range 492-750 $000 \mathrm{mU} / \mathrm{l}$ ) (table II); two of these also had acromegaly (mean of at least four basal plasma growth hormone values between 4 and $23 \mathrm{mU} / \mathrm{l}$ ). One patient (case no 7) had an apparently non-functioning tumour in that circulating prolactin, growth hormone, and cortisol concentrations were normal. Informed and signed consent was given by all the patients after the study had been approved by the ethical committees of the two hospitals. Before treatment with bromocriptine, a detailed evaluation was carried out in each patient, including assessment of visual acuity using a pin-hole correction, visual-field plotting by the same observer using a Goldmann perimeter, and recording visual-evoked potential responses as described. ${ }^{17-19}$ Plain skull radiographs were obtained. CT scans, undertaken on a CT 1010 EMI head scanner before and after injection of contrast material, were used to show only gross changes because of the recognised difficulties in exact head positioning on repeated examinations and therefore of interpretation of small apparent changes. Detailed anatomy was obtained by pneumoencephalography or metrizamide cisternography with anteroposterior and lateral tomograms at $3-5 \mathrm{~mm}$ intervals through the pituitary region including the midline. Blood was sampled at 0900 for thyroxine, testosterone (men), and prolactin (three samples). A standard combined pituitary stimulation test was performed using intravenous thyrotrophin-releasing hormone $(200 \mu \mathrm{g})$, luteinising hormone releasing hormone $(100 \mu \mathrm{g})$, and insulin $(0.15 \mathrm{U} / \mathrm{kg})$, and blood was sampled for serum thyroid-stimulating hormone, luteinising hormone, follicle-stimulating hormone, cortisol, growth hormone, and blood glucose. The patients with acromegaly also had a standard $50 \mathrm{~g}$ oral glucose tolerance test during which blood glucose and serum growth hormone concentrations were measured at 30-minute intervals for two and a half hours and a "growth hormone day-curve" used to obtain a mean circulating growth hormone concentration from samples taken on one day at $0830,1300,1700$, and 1900 as described. ${ }^{5}$

Administration of bromocriptine-After this evaluation, the patients were started on bromocriptine treatment. This was the only drug used and no patient was given any other concomitant treatment for their pituitary tumour. Bromocriptine was started slowly and the first dose was taken during a snack before retiring. The initial daily dose was $7.5 \mathrm{mg}$ in divided doses taken during food, this was increased to between $15 \mathrm{mg}$ and $60 \mathrm{mg}$ daily if necessary until the prolactin concentration was suppressed to within the normal range.

Assessment during treatment-All patients with a visual acuity of worse than $6 / 12$ were monitored in hospital for two weeks, during which time visual acuity was measured daily and the fields were plotted weekly. Thereafter, fields were plotted monthly. Basal endocrine assessment was carried out at least monthly. A further complete re-evaluation was then performed in hospital after three months of treatment and at intervals thereafter. The contrast studies were reviewed by all the participants and only when there was unanimous agreement were the tumours reported as changing in size. If there was no evidence of a reduction in pituitary tumour size by three months, the patients were referred for surgical treatment. The patients were followed up for between three and 22 months (mean $7 \cdot 6$ ).

TABLE II-Effect of bromocriptine treatment

\begin{tabular}{|c|c|c|c|c|c|c|c|}
\hline \multirow[b]{2}{*}{ Case No } & \multicolumn{2}{|c|}{ Prolactin (mU/1) } & \multicolumn{2}{|c|}{ Growth hormone $(\mathrm{mU} / \mathrm{l})^{*}$} & \multirow[b]{2}{*}{ Tumour size } & \multirow{2}{*}{$\begin{array}{l}\text { Pituitary hormone } \\
\text { deficiency }{ }^{\dagger}\end{array}$} & \multirow{2}{*}{$\begin{array}{c}\text { Change in pituitary } \\
\text { hormone reserve }\end{array}$} \\
\hline & Before treatment & During treatment & Before treatment & During treatment & & & \\
\hline 1 & 4000 & 1642 & - & - & Reduced & GH LH & $\mathrm{LH}+$ \\
\hline 2 & 26000 & 1950 & 4 & 4 & Reduced & & \\
\hline 3 & 1243 & $<60$ & 23 & 14 & Reduced & LH TSH ACTH & $\mathrm{LH}+\mathrm{TSH}+$ \\
\hline 4 & 1184 & $<60$ & - & - & Reduced & GH LH TSH ACTH & \\
\hline 5 & 750000 & 130000 & - & - & Reduced & $\mathrm{GH}$ & LH - \\
\hline 6 & 26200 & $<60$ & - & - & Reduced & GH LH & \\
\hline 7 & 132 & $<60$ & - & - & Reduced & $\mathrm{GH}$ & LH - \\
\hline 8 & 3600 & 84 & - & - & Reduced & $\mathrm{GH}$ & $\mathrm{GH}+$ \\
\hline 9 & 25900 & 153 & - & - & Reduced & $\mathrm{GH}$ & \\
\hline 10 & 3840 & 135 & - & 二 & Reduced & GH LH TSH ACTH & $\mathrm{LH}+\mathrm{TSH}+\mathrm{ACTH}+$ \\
\hline 11 & 3435 & $<60$ & 三 & 二 & Reduced & $\mathrm{GH} \mathrm{LH}$ & $\mathrm{LH}+101+\mathrm{NCln}+$ \\
\hline 12 & 3369 & $<60$ & - & - & Reduced & $\mathrm{GH} \mathrm{LH}$ & $\mathrm{GH}+\mathrm{LH}+$ \\
\hline 13 & 3160 & 84 & - & - & Equivocally reduced & $\mathrm{GH}$ & $\mathrm{GH}+$ \\
\hline 14 & 1284 & $<60$ & - & - & Equivocally reduced & GH LH TSH ACTH & \\
\hline 15 & 882 & $<60$ & - & - & No change & GH LH & \\
\hline 16 & 1494 & $<60$ & - & - & No change & GH LH ACTH & $\mathrm{ACTH}+$ \\
\hline 17 & 1609 & $<60$ & - & - & -No change & GH LH ACTH & \\
\hline $\begin{array}{l}18 \\
19\end{array}$ & $\begin{array}{rl}15 & 145 \\
492\end{array}$ & $\begin{array}{r}254 \\
<60\end{array}$ & 二 & 二 & $\begin{array}{l}\text { No change } \\
\text { No change }\end{array}$ & $\begin{array}{l}\text { GH LH } \\
\text { GH LH }\end{array}$ & $\begin{array}{l}\text { LH }+ \\
\text { ACTH - }\end{array}$ \\
\hline
\end{tabular}

* Mean of 4 values during the day. 
Definitions-Hyperprolactinaemia was defined as a mean of three basal serum prolactin concentrations greater than $360 \mathrm{mU} / \mathrm{l}$. In the patients with acromegaly, the clinical presentation was compatible with the diagnosis, and the growth hormone concentration failed to suppress to less than $2 \mathrm{mU} / 1$ during a $50 \mathrm{~g}$ oral glucose tolerance test. Growth hormone deficiency was defined as a rise in serum growth hormone to less than $20 \mathrm{mU} / \mathrm{l}$ and adrenocorticotrophic hormone deficiency as a rise in serum cortisol to less than $550 \mathrm{nmol} / \mathrm{l}(20 \mu \mathrm{g} /$ $100 \mathrm{ml}$ ) during the insulin tolerance test, provided the blood glucose fell to less than $2 \cdot 2 \mathrm{mmol} / 1(40 \mathrm{mg} / 100 \mathrm{ml})$ and there were signs of neuroglycopenia. Patients with luteinising hormone deficiency had either a rise to less than $13 \mathrm{U} / 1,20$ minutes after intravenous luteinising hormone releasing hormone or in the men a subnormal concentration of testosterone at 0900 without concomitant rise of serum luteinising hormone. Patients with thyroid-stimulating hormone deficiency had a subnormal free thyroxine index without a concomitant rise of serum thyroid-stimulating hormone.

Immunoassays-Prolactin and growth hormone were measured by radioimmunoassay, with $M R C 71 / 222$ as prolactin standard and MRC 66/217 as growth hormone standard. ${ }^{20} 21$ Luteinising hormone, follicle-stimulating hormone, and thyroid-stimulating hormone were also measured by standard radioimmunoassays using MRC 68/40 as luteinising hormone standard, MRC $69 / 104$ as follicle-stimulating hormone standard, and MRC $68 / 38$ as thyroid-stimulating hormone standard. ${ }^{22}$ Thyroxine radioimmunoassay utilised Sigma T4 as standard and the thyroid hormone uptake test (Sephadex uptake of ${ }^{125}$ labelled T3) was used to calculate the free thyroxine index. ${ }^{23}$ Testosterone was measured after extraction by radioimmunoassay. ${ }^{24}$ Cortisol was measured by fluorimetry and blood glucose was measured by a neocuproine method.

\section{Results}

Radiological-All 19 patients had grossly enlarged pituitary fossae on plain skull radiographs. CT scans before treatment showed a suprasellar extension in 15 patients and in addition four tumours extended into a cavernous sinus; conventional contrast studies showed a suprasellar extension in 18 patients. One of these 18 patients and one other had a pronounced lateral extension producing oculomotor nerve compression. No pituitary tumour enlarged during treatment (table II). In 12 patients, including the one with the apparently non-functioning lesion, comparison of the contrast studies showed an unequivocal decrease in the size of the pituitary tumour; two others with equivocal shrinkage were not subjected to surgical exploration but were followed up for longer periods. The extrasellar extensions were completely eliminated in seven patients and in two of these a partially empty sella developed 16 and 22 months after starting treatment with bromocriptine.

Ophthalmological-Tilted discs were not present in any patient. ${ }^{25}$ Before treatment visual fields were abnormal in nine patients: upper temporal defects were present in seven, and more extensive defects of vision in the two patients who had had surgery and radiotherapy elsewhere and presented with recurrence of the tumour. The defects improved in seven of the nine affected patients, becoming completely normal in five. Visual-evoked responses were performed before and during bromocriptine treatment in 13 patients. They were normal in three, equivocal in two, and showed abnormalities typical of chiasmal compression in eight. The responses were improved in six patients, unchanged in four, and deteriorated in three. Ptosis and diplopia disappeared in both patients with oculomotor nerve palsies.

Endocrine evaluation (table II)-Prolactin concentrations were raised in 18 patients (range 492 to $750000 \mathrm{mU} / 1$ ). Two of these patients also had acromegaly (mean serum growth hormone 4 and $23 \mathrm{mU} / \mathrm{l}$ ). One patient had a tumour presumed to be non-functioning as there was no evidence of hyperprolactinaemia or acromegaly. Patients with hyperprolactinaemia greater than $2000 \mathrm{mU} / 1$ had a higher incidence of a reduction in tumour size. Thus only two of 11 patients in this group showed no definite change. Five out of eight of the patients with prolactin concentrations below $2000 \mathrm{mU} / \mathrm{l}$ had no clear change in pituitary tumour size. Pituitary hormone reserve was partially or completely deficient in all but one patient before starting bromocriptine. Every non-acromegalic patient (17) was deficient in growth hormone, 13 were deficient in luteinising hormone, six deficient in adrenocorticotrophic hormone, and four in thyroid-stimulating hormone. Pituitary function improved in nine patients, and became entirely normal in three. Some patients regained normal reserves of more than one anterior pituitary hormone-growth hormone secretion became normal in three, luteinising hormone secretion in six, adrenocorticotrophic secretion in two, and thyroid-stimulating hormone in two. Pituitary function deteriorated in three patients; in one of these, no reduction occurred in the size of the tumour and in a second, prolactin concentrations could not be fully suppressed despite a high dose of bromocriptine. On $7.5 \mathrm{mg}$ /day bromocriptine, prolactin concentrations were suppressed to normal in 10 patients; the remaining nine patients required higher doses to suppress prolactin concentrations to normal, but in three, prolactin concentrations could not be suppressed to normal despite at least $30 \mathrm{mg} /$ day of bromocriptine (range 1642-130 $000 \mathrm{mU} / \mathrm{l}$ ). Mean growth hormone concentrations through the day of the acromegalic patients having treatment were 4 and $14 \mathrm{mU} / \mathrm{l}$.

\section{Discussion}

In this prospective study of 19 patients with large extrasellar extensions to their pituitary adenomas treatment with bromocriptine alone decreased the tumour size in two-thirds of patients, the remainder showing no further increase in size of the tumour during the folluw-up. Most of these patients had pituitary tumours secreting prolactin, but a decrease in tumour size has also been shown in patients with pituitary tumours secreting prolactin and growth hormone as well as in one patient with an apparently non-functioning pituitary tumour.

Our criteria for assessing pituitary tumour size were strict. We carried out serial conventional contrast studies with tomography because this is an accepted and accurately reproducible way of delineating the tumour. It is difficult to ensure precisely the same cuts by using serial computed tomography, and serial visual-field determination provides only an indirect means of assessing reduction in the size of a pituitary tumour, as it includes reversal of the pressure effects on the optic nerves. Pituitary size did not diminish in five patients, and pituitary surgery was therefore advised and has been performed in four with improvement in fields in each patient with prior defects. Patients with prolactin concentrations above $2000 \mathrm{mU} / \mathrm{l}$ before treatment showed a higher frequency of tumour shrinkage $(83 \%$ $v 37 \%$ ) but no other factor predicted which patients would respond satisfactorily; tumour size, length of history, apparent vascularity, or consistency of the tumour on CT scanning. Thus both cystic and vascular tumours occurred in the responsive and unresponsive groups.

In addition to the pronounced reduction in tumour mass and neighbourhood symptoms with bromocriptine, pituitary function improved in nine out of 19 patients. This overall improvement contrasts sharply with the alternative surgical treatment, where pituitary function often deteriorates. ${ }^{9}$ The incidence with which pituitary function improves on medical treatment has not previously been assessed in such a large prospective series. Presumably this improvement occurs as a further consequence of the decrease in tumour size, thus allowing the normal pituitary tissue to regain functional contact with the hypothalamus.

Clearly the reduction in pituitary size was a direct effect of the dopamine agonist, bromocriptine. Work in animals has shown that bromocriptine decreases DNA synthesis in pituitary lactotrophs and it has also been shown that oestrogen-induced mitosis is decreased by bromocriptine. ${ }^{26}$ Tumours secreting both growth hormone and prolactin transplanted under the skin in rats decreased in size. ${ }^{2728}$ Bromocriptine may also decrease pituitary tumour size by affecting the vascularity of the gland. Whatever the mechanism of action of bromocriptine, it seems most likely that its property as a dopamine agonist is important because there are isolated reports of other dopamine agonists, particularly lisuride, decreasing pituitary tumour size. ${ }^{29}$

Our findings support those of our earlier retrospective study, which showed a decrease in pituitary fossa size in the plain skull $x$-ray film in 14 of 69 patients treated long term..$^{30}$ We felt then that this incidence of shrinkage was likely to be an underestimate since most patients whose tumours shrink develop a partially empty fossa rather than showing reduction in fossa size. In smaller series of five and six patients with prolactin-secreting adenomas who were subjected to serial studies of tumour size Macgregor et $a l^{31}$ and more recently Prescott et $a l^{32}$ have 
reported that all prolactinomas decrease in size; our experience suggests that this is not always the case but that most do so. Chiodini et al have also studied several patients using serial CT scanning but have not assessed pituitary function. ${ }^{29}$ In their series a large proportion of tumours $(62 \%)$ decreased in size during the period of follow-up. Thorner et al showed in two patients that these decreases in tumour size may occur rapidlysometimes within two weeks. ${ }^{33}$ Spark et $a l^{34}$ reported that 10 of 12 patients showed tumour shrinkage on CT scanning but nine had also had surgical and radiotherapeutic treatment previously.

Until now the management of large pituitary tumours with extrasellar extensions has been unsatisfactory. Surgery rarely renders the patient endocrinologically normal and hypopituitarism is much more frequent after surgical treatment of large than small pituitary tumours; radiotherapy works too slowly to be useful in the urgent occurrence of extrasellar extension to a pituitary tumour. Medical treatment appears to be highly effective in most patients. In patients whose tumours did not decrease in size, vision did not deteriorate during the trial period and subsequent operation performed three months after beginning bromocriptine resulted in a return of the visual fields to normal. Close radiological, ophthalmological, and endocrine supervision is necessary during this time. Particular care should be exercised in the management of patients with severe bilateral visual loss, who have a high risk of persisting visual disability. ${ }^{35}$

The treatment of large pituitary tumours by dopamine agonists is an important advance. Our findings suggest that patients with large extrasellar pituitary tumours should have a trial of bromocriptine before any ablative treatment either with surgery or external pituitary irradiation, as there is a good chance that the tumour will decrease in size and pituitary function will improve. Treatment should continue at least until the tumour is entirely contained within the pituitary fossa, then radiotherapy to reduce tumour growth potential may be considered. Our preferred method of radiotherapy, using a linear accelerator delivering 4500 rads with a three-field technique in 26 fractions over 35 days, is effective and carries no hazards when properly planned.

This work is supported by the Joint Research Board of St Bartholomew's Hospital, the Peel Medical Trust, and the Medical Research Council.

\section{References}

${ }^{1}$ Besser GM, Parke L, Edwards CRW, Forsyth IA, McNeilly AS. Galactorrhoea: successful treatment with reduction of plasma prolactin levels by brom-ergocryptine. $\mathrm{Br}$ Med $\mathcal{F} 1972$;iii:669-72.

${ }^{2}$ Carter JN, Tyson JE, Tolis G, Van Vliet S, Faiman C, Friesen HG. Prolactin secreting tumours and hypogonadism in 22 men. N Englf Med $1978 ; 299: 847-52$.

${ }^{3}$ Franks S, Jacobs HS, Martin N, Nabarro JDN. Hyperprolactinaemia and impotence. Clin Endocrinol (Oxf) 1978;8:277-87.

${ }^{4}$ Thorner MO, McNeilly AS, Hagan C, Besser GM. Long term treatment of galactorrhoea and hypogonadism with bromocriptine. Br Med f 1974; ii :419-22.

${ }^{5}$ Wass JAH, Thorner MO, Morris DV, Rees LH, Stuart Mason A, Jones $\mathrm{AE}$, Besser GM. Long-term treatment of acromegaly with bromocriptine. Br Med F 1977; ; :875-8.

${ }^{6}$ Belforte L, Cammani F, Chiodini PG, et al. Long-term treatment with 2-Br- $x$-ergocryptine in acromegaly. Acta Endocrinol (Kbh) 1977;85: 235-48.

${ }^{7}$ Franks S, Nabarro JDN, Jacobs HS. Prevalence and presentation of hyperprolactinaemia in patients with functionless pituitary tumours. Lancet $1977 ; \mathrm{i}: 778-80$.

${ }^{8}$ Antunes JL, Housepian FM, Frantz AG, et al. Prolactin-secreting pituitary tumors. Ann Neurol 1977;2:148-53.

${ }^{9}$ Pelkonen R, Grahne B, Hirvonen E, et al. Pituitary function in prolactinoma. Effect of surgery and post operative bromocriptine therapy. Clin Endocrinol (Oxf) 1981;14:335-48.

${ }^{10}$ Corenblum B, Webster BR, Mortimer CB, Ezrin C. Possible anti-tumour effect of 2-bromo-ergocryptine (CB-154 Sandoz) in 2 patients with large prolactin-secreting pituitary adenomas. Clinical Research 1975;23:614A.

11 Vaidya RA, Aloorkar SD, Rege NR, et al. Normalisation of visual fields following bromocriptine treatment in hyperprolactinaemic patients with visual field constriction. Fertil Steril 1978;29:632-6.

${ }^{12}$ Friesen $H G$, Tolis G. The use of bromocriptine in the galactorrhoea- amenorrhoea syndromes: the Canadian co-operative study. Clin Endocrinol (Oxf) 1977;6, suppl: 91-9.

${ }^{13}$ McGregor AM, Scanlon MF, Hall K, Cook DB, Hall R. Reduction in size of a pituitary tumour by bromocriptine therapy. $N$ Engl f Med 1979; 300:291-3

14 Landolt AM, Wutrich R, Fellman H. Regression of pituitary prolactinoma after treatment with bromocriptine. Lancet $1979 ; \mathrm{i}: 1082-3$.

15 George SR, Vurrow GN, Zimman B, Ezrin C. Regression of pituitary tumours, a possible effect of bromocriptine. Am F Med 1979;66:697-702.

${ }^{16}$ Hancock KW, Scott JS, Lamb JT, Myles Gibson R, Chapman C. Conservative management of pituitary prolactinomas: evidence for bromocriptine-induced regression. Br F Obstet Gynaecol 1980;87:523-9.

17 Halliday AM, Halliday E, Kriss A, McDonald WI, Mushin J. The pattern-evoked potential in compression of the anterior visual pathways. Brain 1976;99:357-74.

18 Blumhardt LD, Halliday AM. Hemisphere contributions to the composition of the pattern-evoked potential waveform. Exp Brain Res 1979; 36:53-69.

19 Blumhardt LD, Halliday AM. Cortical abnormalities in the visual evoked response. In: Spekreijse H, Apkarian PA, eds. Visual pathways: electrophysiology and pathology. The Hague: W Junk, 1981:347-65. (Proceedings of Documenta Ophthalmologica, series 27.)

${ }^{20} \mathrm{McNeilly}$ AS. Radioimmunoassay of human prolactin. Proc $R$ Soc Med $1973 ; 66: 863-4$.

${ }^{21}$ Forsyth IA, Besser GM, Edwards CRW, Francis L, Myers RP. Plasma prolactin activity in inappropriate lactation. Br Med f 1971;iii:225-7.

${ }^{22}$ Mortimer CH, Besser GM, McNeilly AS, Tunbridge WMG, Gomez-Pan $A$, Hall R. Interaction between secretion of the gonadotrophins, prolactin, growth hormone, thyrotrophin and corticosteroids in man: the effects of LH/FSH-RH, TRH and hypoglycaemia alone and in combination. Clin Endocrinol (Oxf) 1973;2:317-26.

${ }^{23}$ Clarke F, Horn DB. Assessment of thyroid function by the combined use of the serum protein bound iodine and resin uptake of ${ }^{131}$ I-Triiodothyronine. F Clin Endocrinol Metab 1965;25:39-45.

${ }^{24}$ Green JRB, Goble HL, Edwards CRW, Dawson AM. Reversible insensitivity to androgen in men with untreated gluten enteropathy. Lancet $1977 ; \mathrm{i}: 280-2$.

${ }^{25}$ Dorrell D. The tilted disc. Br $\mathcal{F}$ Ophthalmol 1978;62:16-20.

${ }^{26}$ Lloyd HM, Meares JD, Jacobi J. Effects of oestrogen and bromocriptine in vivo secretion and mitosis in prolactin cells. Nature $1975 ; 255: 497-8$.

27 Quadri SK, Lu KM, Meites J. Ergot-induced inhibition of pituitary tumour growth in rats. Science $1972 ; \mathbf{1 7 6}: 417-8$.

${ }^{28}$ Macleod RM, Lehmeyer JE. Suppression of pituitary tumour growth and function by ergot alkaloids. Cancer Res $1973 ; 33: 849-55$

29 Chiodini P, Liuzzi A, Cozzi R, et al. Size reduction of macroprolactinomas by bromocriptine or lisuride treatment. $\mathcal{F}$ Clin Endocrinol Metab 1981; $\mathbf{5 3}: 737-43$

30 Wass JAH, Moult PJA, Thorner MO, et al. Reduction of pituitary-tumour size in patients with prolactinomas and acromegaly treated with bromocriptine with or without radiotherapy. Lancet 1979;ii:66-9.

${ }^{31} \mathrm{McGregor}$ AM, Scanlon MF, Hall R, Hall K. Effects of bromocriptine on pituitary tumour size. $\mathrm{Br}$ Med $\mathcal{F} 1979$;ii:700-3.

32 Prescott RWG, Johnston DG, Kendall-Taylor P, et al. Hyperprolactinaemia in men-response to bromocriptine therapy. Lancet 1982 ; : 245-9.

${ }^{33}$ Thorner MO, Martin WH, Rogol AD, et al. Rapid regression of pituitary prolactinomas during bromocriptine treatment. $f$ Clin Endocrinol Metab $1980 ; \mathbf{5 1}: 438-42$.

${ }^{34}$ Spark RF, Baker R, Bienfang DC, Bergland R. Bromocriptine reduces pituitary tumor size and hypersecretion. Requiem for pituitary surgery ? f $A M A$ 1982;247:311-6.

35 Symon L, Jakubowski J. Transcranial management of pituitary tumours with suprasellar extension. I Neurol Neurosurg Psychiatry 1979;42: 123-33.

(Accepted 28 April 1982)

MEDICINES APPROPRIATED TO THE REINS AND BLADDER-The office of the reins is, to make a separation between the blood and the urine; to receive this urine thus separated from the blood, is the bladder ordained, which is of a sufficient bigness to contain it. Both these parts of the body officiating about the urine, they are both usually afflicted by the vices of the urine. 1. By stones. 2. By inflammation. 3. By thick humours. Medicines appropriated to the reins and bladder are usually called Nephriticals, and are threefold; some cool, others cut gross humours, and a third sort breaks the stone.

In the use of all these, take notice, that the constitution of the reins and bladder is such, that they abhor all binding medicines because they cause stoppage of urine. Take notice, that the reins and bladder being subject to inflammations endure not very hot medicines. Because the bladder is further remote from the centre of the body than the kidnies are, therefore it requires stronger medicines than the kidnies do, lest the strength of the medicine be spent before it be come to the part afflicted. (Nicholas Culpeper (1616-54) The Complete Herbal, 1850.) 